SECTION 30. Philosophy.

Mamaev Sergey Nikolaevich

Specialist of information systems

Naberezhnye Chelny, Russia

snminfo@mail.ru

\title{
INFORMATION THEORY OF CIVILIZATION (synthesis of macrohistorical paradigms)
}

\begin{abstract}
The monograph deals with the largest theme through a relationship between two scientific approaches (paradigms) - civilizational and stage-formational. Dialectical (not contradicting synergy) model was obtained through considering society as an object-system of nature. Formulas of production and the market process were represented for each stage. The basic property of information was defined and historical model was built, which can consider future as well.
\end{abstract}

Key words: civilization, formation, information, historical-futurological model.

\section{ИНФОРМАЦИОННАЯ ТЕОРИЯ ЦИВИЛИЗАЦИИ (синтез макроисторических парадигм)}

\begin{abstract}
Аннотация: В монографии рассматривается крупнейшая тематика через взаимосвязь двух научных подходов (парадигм) - иивилизационного и стадиальноформационного. Рассматривая общество как объект-систему живой природь, получена диалектическая (не противоречащая синергетике) модель. Представлень формуль производственно-рыночного прочесса для каждой стадии. Определено основное свойство информачии и построена историческая модель с расширением в будущее.
\end{abstract}

Ключевые слова: цүивилизачия, формация, информация, историкофутурологическая модель.

\section{Глава 1.}

Универсальная социально-экономическая теория (синергетический аспект концепции устойчивого развития)

В конце XX века в связи с критическим состоянием экологии была осознана необходимость создания концепции устойчивого развития (как условие выживаемости человечества), в рамках которой мог бы быть описан исторически непротиворечивый процесс развития общества с положительной экологической перспективной составляющей.

Со времени проведения первой конференции ООН (Рио-де-Жанейро, 1992), однако, так и не выявлено научного (натурфилософского, синергетического) аспекта проблемы устойчивого развития. «Главные идеологии индустриализма - либерализм и марксизм - не подготовили массовое сознание к таким выводам. Более того, интеллектуальные течения, следующие постулатам обеих идеологий, практически ничем не ответили на Рио-92. Во всяком случае, не известно попыток провести ревизию главных постулатов этих идеологий в свете решений этой Конференции. Пока что главный ответ на констатацию краха главной модели развития целой цивилизации полное молчание» (Кара-Мурза [3]). И так доныне. 
Основной смысл устойчивого развития - преодоление отрыва современного человека от природы при обеспечении равного удовлетворения потребностей в развитии и в качестве жизни, включая качество окружающей среды, уровень жизни, культуры и образования людей.

Синергетический подход требует анализа социальной и политэкономической ситуации в современном мире и историческом аспекте. Коренные изменения ситуации привели к необходимости отказа от превалирования глобально-аморфных понятий мировых систем - "капиталистической" и "социалистической" как не вписывающихся в концепцию устойчивого развития и актуализации других парадигм социальной онтологии.

Социалистическая система распалась, но капиталистическая все еще воспринимается в виде целого, некоего глобального сверхобщества, доминирующего в современном мире. Однако противоречия внутри нее больше не компенсируются наличием общего противника, каким была мировая социалистическая система.

Коммунисты выстраивали идеологию на основе стадиально-формационной парадигмы, извратив ее. Западные идеологи основываются на цивилизационной парадигме, в результате - конец истории и глобализация, ведущая к краху. Т.к. другие парадигмы отсутствуют, необходим синтез парадигм, освобожденных от идеологического налета.

Перечень основных цивилизаций современности весьма традиционен и не имеет больших отклонений. Рассматривая его в своей работе, Розов [9] делает всего одно допущение - помещает Россию в центр весьма проблематичной Евразийской цивилизации. Однако если вернуться на два десятилетия назад, то в соответствии с подходом, существовала другая цивилизация - коммунистическая, закончившая свой круг и пришедшая в упадок, в полном соответствии со структурой всех цивилизаций: рождение - рост - расцвет - надлом - упадок.

Перечень основных цивилизаций выглядит следующим образом:

1. Западная (почти то же, что и старая "мировая капиталистическая система").

2. Восточная (Розов делит ее на Южно-Азиатскую и Дальневосточную цивилизации).

\section{3. Исламская.}

4. Коммунистическая (или "социалистическая система" - во главе с СССР).

Необходимо отметить, что каждая цивилизация обладает собственной культурой (и системами, например, правовой), призванной поддерживать ее жизнеспособность на интуитивном уровне, тем самым позволяя выдерживать определенный курс развития.

Данный подход не только практически включает мировые системы в цивилизационную парадигму (отдельные моменты могут быть объяснены через взаимодействие и взаимопроникновение цивилизаций), но и оставляет перечень цивилизаций открытым, разрешая дополнять его как другими (меньшими) цивилизациями, так и новыми, по мере их появления или возможного выделения из существующих.

\section{Западная цивилизация.}

Другая парадигма социальной онтологии - стадиально-формационная - основана на западноевропейской истории. Из этого априори следует, что западная циивлизаџия развивается последовательностью стадий (формаций). Стадиальность требует отрицания низшей стадии, формационность - целостности. 
Нравственная основа западной цивилизации - христианство, ставшее в первую очередь основой перехода от рабовладельческого общества к феодальному путем объявления грехом прямого убийства человека, в том числе раба.

Переход к следующей стадии - капиталистической - потребовал преобразований в самом христианстве (один из крупнейших исследователей этого вопроса Вебер связывает дух капитализма с протестантской этикой).

Если основываться на стандартной стадиально-формационной «пятичленке», то следующей стадией западной цивилизации должна стать социалистическая, которая в полной мере еще не достигнута. Из-за неопределенности в терминологии она страдает многовариантностью толкования (еще более аморфна в этом смысле коммунистическая стадия, которая вынесена за границы обзора, чтобы не возникло путаницы с распавшейся коммунистической цивилизацией).

Кроме того, «пятичленка» как последовательность первобытной, рабовладельческой, феодальной, капиталистической и социалистической стадий не совсем полна потому, что текущее состояние развитых стран - государственный капитализм - вполне может являться отдельной стадией, следующей за капиталистической и предшествующей социалистической (существенно информационной).

Переход с одной стадии на другую связан с состоянием нестабильности и сопровождается революциями и войнами (что является неотъемлемой частью как марксизма так и либерализма). В рамках одной стадии развитие осуществляется эволюционным путем, но до определенных границ.

Существование стадиально-формационной парадигмы определяет, что западная цивилизация непрерывна в том смысле, что нельзя перескочить через стадию или поменять стадии местами (это положение было извращено коммунистами, что, вкупе с игнорированием цивилизационной парадигмы, привело к краху СССР). Однако, возможен отход от основного «русла» западной цивилизации на некоторое время, но вернуться можно только на ту же стадию.

Эта цивилизация является одной из наиболее протяженных во времени, а так как она ориентирована на материальные ценности и определение отношений в сфере труда, то и придет к своему естественному завершению только тогда, когда достигнет общественной оценки всех типов этих отношений. Следовательно, соотношение с западной (материальной и рациональной) цивилизацией достаточно для оценки экономического уровня любой другой цивилизации. Более того, иного пути материального развития, кроме как в необходимой мере «вписаться» в определенную стадию, видимо, не существует.

Современное понятие развитой экономики связано с производственно-рыночной ориентацией западной цивилизации, поддерживаемой материальной культурой как основной составляющей общей культуры.

Рыночные отношения могут на отдельных этапах регулироваться определенными (государственными или другими) структурами, в том числе через воздействие на материальную культуру путем создания и поддержки идеологии.

Западная цивилизация, как отмечает Кара-Мурза [3], породила техноморфное представление о мире, идеологии которого, основываясь на производственных отношениях, одинаково потребительски, если не хищнически, относятся к природе потому, что в западной политэкономии и экономических теориях представление о бесконечности мира превратилось в постулат о неисчерпаемости природных ресурсов. Материальная культура имеет безусловный приоритет над природой. В экономической терминологии природные ресурсы являются бесплатными, поэтому вместо «добываются» или «извлекаются» часто используют термин «производятся», что лишает труд сакрального смысла и позволяет разделять его по функциям. 


\section{Традиционные цивилизации, диалектика труда и философский аспект концепции устойчивого развития.}

Цивилизационная модель - это совокупность наиболее общих принципов построения системы взаимодействия человека и природы на определенной территории c eе ресурсами и природно-климатическим потенциалом при заданном уровне материально-технического развития. Таким образом, цивилизация в научном смысле представляет собой почти единый организм (принцип биосоциальности), что имеет как преимущества (согласованное функционирование всех систем организма и т.д.), так и недостатки (смертность организма и т.д.).

На таком определении основывается понятие традиционных цивилизаций, изначально относившееся к цивилизациям древности, для которых отношение к природе соответствовало отношению к матери, поэтому эксплуатация природы была не возможна, поскольку не было основ для производственной деятельности как целенаправленного воздействия на природу и в первую очередь на землю. Труд на земле не имел своей целью личное обогащение и отсутствовало его разделение по функциям (как основа производства), однако свободный крестьянин чередовал труд на земле с ремесленным, ратным трудом, торговлей во время ярмарок и даже законодательным (при участии в вече). Следовательно, существовало разделение труда по видам (во времени, что отличает традиционные цивилизации от первобытных племен). Крестьянское семейное хозяйство, использующее такой труд (субъективный), является гораздо более жизнеспособным в критических условиях (согласно чаяновским исследованиям), чем рыночное, производственное хозяйство.

Цивилизационная составляющая превалировала и в Древней Греции. Маркс (во времена которого цивилизационный подход еще не был развит) предпочитал говорить, как замечает Гуревич [2], не о «рабовладельческом способе производства, а об «античной формации». Эти понятия никоим образом не синонимы, ибо, как Маркс не раз подчеркивал, базис античного общества образовывал труд свободных крестьян и ремесленников, а не труд рабов». В данном случае понятие формации больше соответствует по смыслу современному понятию цивилизации, тогда как стадия определяется способом производства. В цивилизационной парадигме древнегреческое общество является традиционным, находящимся на стадии рабовладения как производственная формация.

Цивилизационная парадигма вполне может быть основанием тех цивилизационных моделей, заданный уровень материально-технического развития которых соответствует определенной стадии рыночной цивилизации.

Следовательно, диалектика труда заключается в способе его разделения - по функциям или по видам, а философский аспект концепции устойчивого развития состоит в согласовании стадиально-формационной и цивилизационной парадигм, что позволит преодолеть или нивелировать недостатки подходов. Согласование парадигм требует не только синтеза, но и придания парадигмам более четких контуров, например, аналитического выявления новых составляющих производства и рынка и соответствующего преобразования во взгляде на общество и трудовую деятельность как из одной, так и из другой парадигм.

\section{Способы производства.}


Рациональность - судьба западной цивилизации (по Веберу [1]), тот культурный феномен, который позволяет, пользуясь силой разума и способностью человека к расчету, организовать производство и реализовать обмен на рынке. Производство и рынок объединяет общее условие существования - разделение труда по функциям (в пространстве), которое ведет к специализации.

Из принципа рациональности следует, что участвовать в процессе производства могут только свободные люди, так как зависимый человек (например, раб) не рационален, ибо подчинен расчету владельца. При капиталистическом способе производства капиталист покупает рабочую силу у ее владельца - рабочего - на время производства, причем оба действуют рационально, так как один получает от этого прибыль, а другой заработную плату.

Тогда из существующих теорий совершенно не ясно, кто чего покупает при рабовладельческом способе производства и какие свободные люди участвуют в нем? И на какие объекты происходит воздействие в процессе рабовладельческого производства? Это предстоит выяснить.

В (экономической и политэкономической) теории наиболее широко определяется, что производство есть процесс воздействия человека на природу (природные объекты, ресурсы) с целью создания материальных благ и услуг, необходимых для развития общества.

Природные ресурсы, на которые происходит производственное воздействие, должны непрерывно воспроизводиться, то есть быть (либо выглядеть) неисчерпаемыми. По Марксу [6] даже «если люди целые столетия живут грабежом, то должно, очевидно, постоянно иметься что-нибудь, что можно грабить, другими словами - предмет грабежа должен непрерывно воспроизводиться» (Маркс не находит такого предмета, исходя из капиталистического способа производства и экономики, хотя и не отрицает, что в древнем мире превалировала политика, а в средние века католичество).

Первое условие существования производства, следовательно - наличие неисчерпаемого природного ресурса (природных объектов).

Другим условием является наличие соответствующих средств производства, через которые природные ресурсы опосредствуются трудом (не опосредованные трудом потребительные стоимости по Марксу не могут быть меновыми стоимостями), причем средства производства различны для каждой стадии (на рынке находящиеся в собственности свободных агентов).

Третье условие - применение определенного способа получения (и/или распределения) прибавочной стоимости (защищается институтами), соответствующего способу производства.

Возвращаясь к рабовладельческому способу производства необходимо особо отметить, что труд на земле в те времена не мог быть производственным, иначе земля быстро бы истощилась, так как неизвестно никаких новых способов ее обработки, отличных от тех, которые применялись еще земледельческими племенами. С другой стороны, хорошо известно отношение к рабу как к вещи, движущемуся предмету машине, человеческому материалу, который надо было сначала заполучить.

Информацию о возобновляемых ресурсах можно получить из древних источников. Еще Энгельс [13] утверждал, что генеалогия, выдаваемая за генеалогию Ноя, Авраама и т.д., является довольно точным перечислением бедуинских племен того времени по степени родства их диалектов. Следовательно, от родов и племен возможны многие сыновние ответвления - новые племена (прежде чем племя, быть может неизбежно, закончит свое существование) и люди «диких» племен представляют собой тот материал, который необходим для производства. Тогда сам процесс производства - 
это набеги, целенаправленные военные действия, а средства производства - оружие, принадлежащее вождю, военачальнику (сам строй правильнее бы называть рабозахватническим). Прибавочную стоимость создают рядовые воины, легионеры, эксплуатируемые на политическом рынке с целью захвата рабов. Труд же рабов использовался в самых традиционных видах деятельности (для интенсификации рабского труда в экономику с политического производства переносились методы, с помощью которых раб добывался - методы физического воздействия).

Производственно-рыночная формация имеет несколько иной смысл, чем марксистская общественно-экономическая, так как Маркс исходил из аристотелева определения экономики как хозяйственной деятельности, которая далеко не всегда рыночная (более того, экономика и рынок - хрематистика - Аристотелем часто противопоставляются). В Древней Греции еще не в полной мере развернуты рабовладельческий рынок и производство, так как еще сильно сакральное отношение к земле, для обработки которой рабы не допускались, а использовались в сфере ремесла (как и иностранцы).

Политическое производство стало господствовать в Римской империи при использовании рабского труда в сельском хозяйстве и господствовало до тех пор, пока было кого завоевывать. Завоевания, расширявшие владения империи, все более отдаляли объекты производства (добычи) рабов. Рабский же труд отнюдь не эффективен и его результат зависит от количества новых рабов, так как раб вырождается уже в третьем поколении. На границе эпох наступил системный кризис рабовладения, отмечавшийся древнеримскими мыслителями (Сенека и др.). Начинает формироваться новый способ производства - феодальный, основанный на воспроизводстве колонов на внутренней территории. Раб получал земельный надел либо мастерскую - пекулию и, становясь крепостным, платил оброк. Возникают противоречия между способами производства, так как, с одной стороны, раб, как и свободный человек, получил право иметь собственных рабов, а с другой, его детей владелец мог отобрать и продать еще в раннем возрасте. Противоречия погубили империю. Возобладал новый способ производства - феодальный, поддерживаемый новой идеологией - христианской. Естественно, необходима была организационная структура, которая защищала бы крепостного от убийства феодалом и его семью от разделения - католическая церковь, получавшая за это десятину. Однако церковь отнюдь не противилась феодалу при продаже крепостных семьями либо достигших самостоятельности взрослых детей. Так как «защищать права» крепостных необходимо и во время их продажи, то католическая церковь сама и организовывала этот процесс, часто пользуясь всеми привилегиями монополиста (достаточно вспомнить вольтеровскую критику деятельности церкви).

Капиталистический же способ производства сформировался тогда, когда производство стало использоваться в промышленности - с переходом от цеха к мануфактуре при многократном увеличении производительности труда путем его разделения по функциям.

\section{Взаимодействие и взаимопроникновение цивилизаций.}

В последнее время произошел резкий подъем экономики многих дальневосточных государств, ощутивших положительное влияние со стороны западной цивилизации на рост собственного материального благосостояния.

Одной из первых в этом списке стоит Япония, которой были буквально навязаны основные экономические принципы западной цивилизации со стороны США 
после второй мировой войны. Розов [9] отмечает, что в Японии в средние века существовал государственный строй, практически полностью соответствующий феодальной стадии западной цивилизации, следовательно, уже тогда японская культура материальных отношений была достаточно близкой к культуре западной цивилизации, что в достаточной мере сопутствовало развитию японской экономики, даже учитывая приоритет национальных традиций при интеграции подходов.

Моисеев [7] относит Японию к традиционной цивилизации конфуцианского корня, имеющую огромный технологический потенциал, основываясь на котором, Япония продвинулась на пути к постиндустриальному обществу.

Этот опыт можно считать принципиальным, показывающим возможность взаимопроникновения западной и восточной (или одной из восточных - островного типа) цивилизаций в современном мире (при наличии собственной правовой системы).

В дальнейшем эта возможность была реализована в более мягком виде - без военного присутствия, но при жестком соблюдении курса - в Южной Корее, Сингапуре.

С недавних пор по подобному пути пошел Китай.

Китай первым из крупных представителей коммунистической цивилизации стал проводить экономические реформы, сделав тем самым первый шаг к распаду старой коммунистической и к возврату к приоритетам собственной цивилизации, но с ориентацией на рыночную экономику (реформированный коммунизм).

Второй шаг в направлении рынка (и не только в экономике) сделала Россия и коммунистическая цивилизация распалась.

Советский Союз как центр коммунистической цивилизации родился на месте пришедшей к закату Российской империи.

Российская империя также имеет признаки цивилизации как единой системы нравственно-культурной и политико-экономической организации общества при наличии государственной религии - православия, сословности и крепостной зависимости крестьянского сословия, а также преемственности власти в рамках династии Романовых. Обобщенно эту цивилизацию можно охарактеризовать как православно-крепостническую.

Еще более ранняя система организации русского общества, связанная с династией Рюриковичей, коренным образом отличается от организации последующей Российской империи отсутствием крепостной зависимости и превалированием древнерусского язычества над еще не ставшей государственной православной идеологией. Русь того времени сильно разнородна и если еще не цивилизация, то уже прообраз цивилизации, но почти при полном отсутствии самостоятельной экономической производственной составляющей, практически все проблемы решались на политическом уровне, как свидетельствует «Русская правда» Я. Мудрого. Следует заметить, что упадку Руси предшествует, по словам Тойнби [11], вестернизация окраинных и внутренних земель Московии.

Древнерусскую протоцивилизацию сменила православно-крепостническая цивилизация, а ее в свою очередь сменила коммунистическая. В промежутках между цивилизациями - "смутное время". Следовательно, Россия развивается последовательностью чивилизачий.

Можно выделить некоторые общие черты, свойственные российским цивилизациям. Каждая новая цивилизация начинает формироваться путем движения в сторону современного ей состояния западной цивилизации, но собственными методами.

К сожалению, выстраиваемые Россией евразийские цивилизации были не очень устойчивы, зато не погибала сама Россия, даже в «смутные времена», 
продолжительности которых хватало, чтобы создать условия для становления новой цивилизации.

\section{Западная цивилизация и США.}

В начале XX века коммунисты претендовали на создание мировой цивилизации путем "мировой революции". Известно, что их надежды не вполне оправдались. Нашелся достойный противник в споре за "мировое господство" - западная цивилизация во главе с США.

Соединенные Штаты Америки в противостоянии двух цивилизаций должны были развиваться не менее динамично по всем направлениям материального производства (по принципу равных возможностей), чем СССР как лидер коммунистической цивилизации, налегающий на приоритетные направления в ущерб остальным. Развиваться ускоренными темпами североамериканцам не привыкать, в собственной истории они прошли путь от рабовладения до государственного капитализма всего за три века.

После распада СССР темпы развития США не замедлились, а их организация все более стала напоминать собственную цивилизацию с превалирующей религией и оригинальной культурой, своеобразной политической системой (демократы и республиканцы) и новейшей формой мировой экспансии - информационной - через глобальные компьютерные сети типа "Интернет". Правда, информационные технологии могут оказаться ловушкой успешных стратегий (по Розову [9]), так как слабо защищены, да и культура за их развитием не поспевает, чему примером многочисленные хакеры и писатели компьютерных вирусов.

Следствием этого строительства Соединенными Штатами собственной цивилизации, все более отдаляющейся от «стандартной» западной, являются возрастающие финансовые (между долларом и евро), военно-политические (внутри НАТО) и другие разногласия США с западноевропейскими государствами, а также стремление к экономической самодостаточности.

Поэтому «скороспелая» цивилизация США может гораздо раньше Западной Европы подойти к следующей стадии западной цивилизации со всеми вытекающими последствиями переходного периода.

\section{Государственное регулирование.}

С развалом коммунистической цивилизации начался процесс возврата России в то же состояние относительно западной цивилизации, от которого она отходила на рубеже первой четверти XX века - в состояние капитализма, который скрупулезно описан в трудах Маркса, а сейчас в просторечии называют диким капитализмом. "Молодые реформаторы" никогда и не скрывали, что проходили этап первоначального накопления капитала, затем начали этап концентрации капитала, что строго по Марксу привело к олигархиям.

Возврат осуществился, но теперь особо актуальной стала проблема государственного регулирования рынка как способа вывода экономики из тупика дикого капитализма.

Регулированием можно заниматься в большей или меньшей степени, оставаясь в рамках капитализма в клановом, номенклатурном либо олигархическом варианте, но если ставится задача построения государственного капитализма, то в любом случае необходимо сильное государство, а результат будет зависеть от способа регулирования:

1-й способ - Государство само становится участником капиталистического рынка, естественно, привилегированным, быстро увеличивая количество принадлежа- 
щей ему собственности. Предприятия группируются по монопольным признакам, затем монополии объединяются в сверхмонополию и государство в конце концов становится единственным участником рынка, монопольно захватившим всю экономику. Рынок проглядывает только в теневых сферах. Как пишет Леонтьев [5], «Основное положение, которое объясняет высокие темпы роста советской экономики, достаточно просто. Оно было четко сформулировано почти двести лет тому назад Адамом Смитом, а более доступным языком - Бенджаменом Франклином. Для быстрого увеличения своих доходов необходимо направить как можно большую часть - а затем и еще большую - на инвестиции в производственный капитал. Это означает, что необходимо сократить потребление, понижая таким образом жизненный уровень масс; необходимо в то же время заставлять их работать в поте лица. Маркс в своей теории накопления капитала описывает точно такой же процесс, за тем исключением, что он говорит о нем в уничижительных выражениях: владельцы средств производства используют свое монопольное положение по отношению к рабочему классу для роста прибыли и сдерживания заработной платы. Низкая заработная плата означает низкий уровень потребления. Высокая прибыль, то есть высокий «уровень эксплуатации», означает высокую скорость накопления, так как капиталисты всегда стремятся увеличить свой капитал для того, чтобы иметь возможность успешнее конкурировать друг с другом, а также нанимать больше рабочих с целью их эксплуатации. На протяжении тридцати лет \{к 1960 году $\}$ коммунисты в России строго следовали этому предписанию».

Фактически данная система является системой одного завода (по Моисееву [7]).

2-й способ - Государство не вмешивается в рыночную экономику (кроме естественных монополий), предоставляя рынку функционировать по собственным правилам и запрещая чиновникам заниматься коммерцией, поддерживая, регулируя и направляя рынок исключительно граничными методами, в основном налогами, а также контролируя процедуры, например, банкротства. Устанавливая слишком большие налоги, государство рискует нарушить рыночный механизм, и рынок из прозрачного состояния перейдет в теневое, которое практически не регулируется, a, следовательно, автоматически происходит возврат к дикому рынку.

Нетрудно видеть, что первый способ регулирования присущ разного рода "социализмам", второй - способ развитых стран, открывший новый этап в развитии западной цивилизации и являющийся определяющим в понятии экономической демократии, которую в отличие от политической в России так и не удалось выстроить за последнее десятилетие. Это принципиальный момент, так как пока экономическая демократия отсутствует, то остается возможность даже для феодального рецидива.

Третьего способа государственного регулирования не существует, так как первые два являются противоположными относительно функций государства.

\section{К универсальной экономической теории западной цивилизации.}

Должна существовать непосредственная взаимосвязь концепции устойчивого развития с социальной теорией или той ее частью, которая описывает западную цивилизацию.

Теорией является система гипотез, которые проверяются на практике по отдельности, но особенно важна целостность и непротиворечивость системы. Шрейдер [12] утверждает, что «можно говорить не только о выборе отдельных гипотез в рамках развиваемой теории, но и о выборе самой теории как системы гипотез, на которую должна опираться новая теория». Следовательно, должен быть соблюден принцип соответствия (преемственности) при описании логической конструкции «идеального 
типа» (марксово «учение о формациях не представляет собой «идеального типа»орудия познания». Гуревич [2]).

Первый вопрос социальной теории - социальное пространство. Социальное пространство, как отмечают Потемкин и Симанов [8], является аристотелевым - это совокупность мест, занимаемых телами. Оно ограничено. «Человек, формируя свои представления о мире на основе индивидуального и социального опыта, формирует тем самым социальное пространство». С этой же объективной позиции могут рассматриваться политическое и экономическое пространства. Однако, авторы приводят и критические замечания по поводу возможности согласования социального пространства с физическим.

Второй вопрос социальной теории - вопрос о ее главных компонентах. Эти компоненты должны быть обобщением свойств реальных объектов в общественном восприятии и деятельности. Необходимо установить связь компонентов между собой и с физическим миром. Например, преодолеть однобокость представления, в котором товары у Маркса не являются реальными объектами.

Третий вопрос - объект исследования. Объектом исследования является производство для рынка. Моисеев [7] рассматривает Рынок (с большой буквы) как объективный механизм самоорганизации, применяемый не только обществом, но и природой.

Пересечением социального пространства и рынка является пространство рынка. Рыночное пространство, как и социальное пространство, создается людьми (обществом) и за его пределами законы данного рынка работать не могут. Возможно одновременное существование двух или более рыночных пространств, следовательно, столько же рынков. Существует также механизм регулирования рынка. Применительно к природе он называется естественным отбором. Экономический рынок на определенных этапах регулируется, например, государством.

Рыночное пространство осваивается с помощью производства (объективную сторону которого выявил Маркс как почти физическую, следовательно, именно рыночное пространство соответствует по структуре однородному и изотропному физическому пространству) и определяется способом производства.

Ниже излагаются основы теории западной цивилизации (стадиальноформационная парадигма) в терминах политэкономии, так как именно политэкономическое представление исходит из производства.

\section{Направление развития.}

Уже более 15-ти лет отечественные экономисты пытаются обойтись вообще без какой-либо политэкономии, что в основном отрицательно сказалось на производстве. Эта ситуация требует дополнительного анализа в первую очередь положений политэкономии Маркса и границ ее применимости с тем, чтобы предложить способ их преодоления.

Трудовая теория стоимости основывается на товарно-денежных отношениях, где товар является вещью. Товарно-денежные отношения, однако, нельзя считать основной характеристикой даже предыдущей стадии развития общества - феодальной. В "Капитале" Маркс [6] пишет: "Но ни хлеб, отчуждавшийся в виде оброка, ни хлеб, отчуждавшийся в виде десятины, не становился товаром вследствие того только, что он произведен для других. Для того чтобы стать товаром, продукт должен быть передан в руки того, кому он служит в качестве потребительной стоимости, посредством обмена". В феодальном же натуральном хозяйстве внешний товарный обмен минимален. Следовательно, политэкономия Маркса не описывает предыдущие стадии в развитии 
общества, тем более не будет описывать следующие за капитализмом (это вынужденно отмечалось еще в ленинском обосновании НЭПа).

Основным понятием расширенной политэкономии является производственный труд, присущий природе человека. В общем виде Труд и природу человека (Пч) можно интерпретировать как субстанции.

Тогда рабочая сила (Рc) и товар (Т) являются промежуточными субстанциями между природой человека и трудом под их общим воздействием.

Относительно труда весь процесс экономического развития можно представить как процесс последовательного приближения к его адекватной общественной оценке. Тогда общий процесс является последовательностью особенных процессов производств продуктов труда:

$$
\begin{gathered}
\text { - - Пч ------ Рс ----- } \mathbf{T} \text {----- Труд - - } \\
\text { направление развития труда }
\end{gathered}
$$

Идеальная цель экономического развития - производство системы жизнеобеспечения (труд позволяет человеку создать систему своего жизнеобеспечения, но пока на рынке нельзя купить такую систему, которая целиком и полностью обеспечивает жизнедеятельность или ее вид - такая система должна быть биотехнической).

Рабочая сила, как способность человеческого организма к производственному труду, не только должна формироваться на основе самой природы этого организма, но и стать на некотором этапе самовосполнимой (термин Маркса). И на этом ее путь не заканчивается - в конце своего развития она становится товаром, на котором строится все здание капитализма. Затем наступает очередь общественной оценки товара, его самовосполнимости (что касается понятия "самовосполнимость", то его можно рассматривать через современные понятия целостности и синергетической самоорганизованности).

Следовательно, особенные процессы можно разделить на два последовательных единичных процесса. Первый - создание многообразия продуктов труда количественная стадия. Второй процесс - достижение самовосполнимости продукта качественная стадия.

Тогда полная модель будет выглядеть следующим образом (каждая стадия общественно-производственная формация со своими производственными отношениями): 
Пч колич.

$\downarrow \quad$ Первобытнообщинная

Пч кач.<smiles>[13CH3]</smiles>

Рабовладельческая

Рс колич.

$\downarrow$

Феодальная

Рс кач.

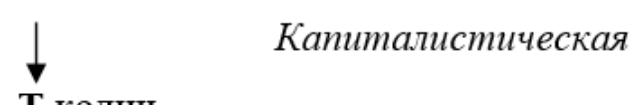

Т колич.

$\stackrel{\downarrow}{\mathbf{T}}$ кач.

Государственно-капиталистическая

$\downarrow$

Сочиалистическая

Труд колич. (система)

$\downarrow$

Постиндустриальная

Труд кач. (система)

Данная последовательность этапов полностью соответствует законам диалектики: единства и борьбы противоположностей (труда и природы человека в виде их совместных объективных проявлений); перехода количества в качество и наоборот; отрицания отрицания (каждое следующее отношение отрицает предыдущее).

Общая теория систем (ОТС) Урманцева [15] позволяет представить объектсистему в системе объектов одного и того же рода. Тогда последовательность формаций в этом представлении соответствует симметричной диалектической модели:

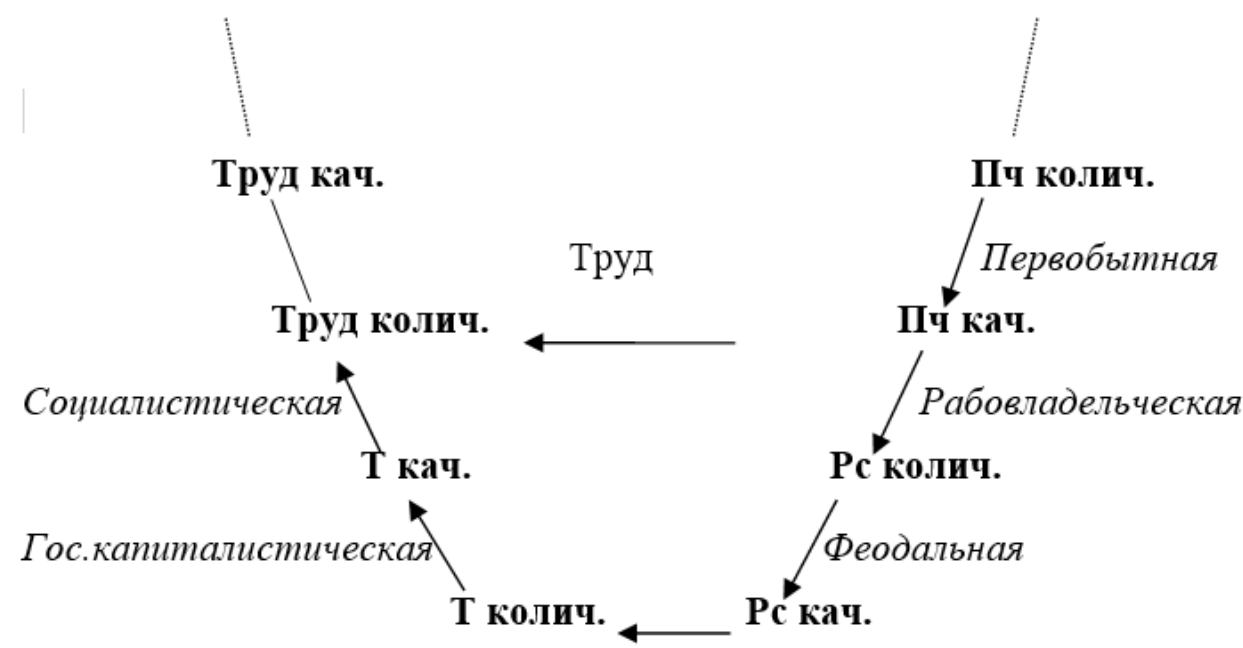

Капиталистическая

На каждом этапе выполняются такие соотношения как меновая стоимость (ценность относительно Труда), например, Т к Труду, и потребительная стоимость (ценность относительно Пч), например, Рс к Пч. Последняя модель может представлять собой виток спирали.

\section{Типы рынка и систем регулирования.}


Полученная модель отражает наличие рыночной экономики трех типов, каждому из них соответствует отдельная стадия, в течение которой происходит формирование данного рынка (в конце стадии - идеальный рынок):

1) рабовладельческий - рынок Рабочей силы (рабов), абсолютный (фундаментальный) рынок - продается все, прибавочную стоимость приносит входящая в рабочую силу природа человека, можно даже себя продать в рабство;

2) капиталистический - рынок Товара, отсекается рынок рабов, каждый свободно продает свою рабочую силу в виде специфичного товара, приносящего прибавочную стоимость;

3) социалистический - рынок Труда - биотехнические системы жизнеобеспечения (не путать с «рынком трудоустройства»), отсекается рынок товара, каждый свободно продает свой товар в виде труда (как его составную часть, приносящую прибавочную стоимость).

Каждый тип рынка не только отрицает предыдущий, но и в свое время вводит элементы последующего.

Каждому рыночному пространству свойственна собственная информационная среда и соответствующая степень территориального распространения (пространственного ограничения).

Идеальный рынок - состояние неустойчивое, как видно на примере США и Западной Европы конца 20-х годов XX века («чистый» капитализм, как утверждал В. Леонтьев, может довести экономику до беды). Поэтому за этапом формирования рынка следует этап его регулирования, причем за время доведения системы регулирования до идеального состояния должно быть создано пространство нового рынка и соответствующий ему новый способ получения прибавочной стоимости.

Стадии развития системы регулирования:

1) феодальная - регулирует рынок Рс (регулируемое рабовладение, его основа запрет на убийство раба), повышая ее качество (до достижения самовосполнимости) и сложность (простая количественная Рс входит в качественную, следовательно, последняя становится составной); формируется простейшая система внутреннего управления - иерархическая.

2) гос. капиталистическая - регулирует рынок T (на уровне отдельного предприятия выстраивается система управления, позволяющая постоянно повышать качество производимого товара и его сложность); система управления неиерархическая.

Общество, не имеющее большого рыночного опыта, способно показать свои преимущества на этапах, где наиважнейший фактор - адекватная рынку система регулирования (в виде системы управления).

Однако пример СССР доказывает, что зарегулированная всеми способами система также не соответствует устойчивому развитию. Коммунистическая цивилизация тоже оказалась смертной.

Переход с одной стадии на другую - политический и нравственный процесс формирования новой материальной культуры, идеологии, общественного согласия на экономическую деятельность в рамках нового способа производства и получения прибавочной (добавочной) стоимости. 


\section{Деньги.}

Универсальное изобретение - деньги, соответственно меняя свою форму, каждый раз остаются средством общественной оценки взаимодействия тех базисных компонентов, которые являются экономической сущностью данной формации (Д денежные инвестиции, Дф = Д + прибавочная стоимость, П - процесс производства в денежной форме, Сп - соответствующие базису средства производства; и процесс и средства производства качественно отличные для каждой формации):

1 .

Рабовладельческая: Д - Рс кол.

\section{Пч кач.}

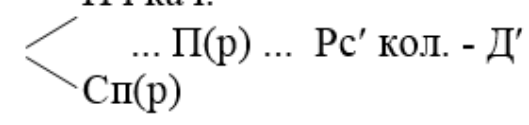

Производство в первую очередь рабозахватническое. Военачальник приобретает необходимую для него рабочую силу - воинов (как Пч) и оружие (а также транспорт и др.) как средства производства рабозахватнические $($ Сп(р)). Процесс производства военный набег, в результате которого он получает пленных воинов, рабов и добычу. Оборот медленный, но прибыль большая. Рабы продаются (например, на древнеримских базарах).

Деньги на данной стадии являются не только средством обмена, но и атрибутом власти человека над человеком (рабовладельца над носителем Пч - рабом, который не владеет правом иметь деньги). Прибавочная стоимость при повседневной деятельности зависит от количества рабов, выполняющих простейшие виды работ и, поэтому, легко заменяемых практически без обучения. Производственное воздействие на природу заключается в целенаправленном физическом воздействии на ее часть - природу человека, как в процессе добывания раба, так и в процессе его традиционного труда. Но раб быстро вырождается.

Форма денег - слитки металлов, монеты. Период денежного оборота велик, в промежутках между инвестициями в добывание новых рабов за счет завоеваний денежные средства хранятся как сокровища.

2 .

Феодальная:

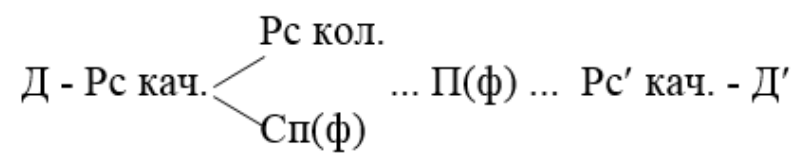

Формула отражает процесс производства рабочей силы, при котором повышается ее качество, способной содержать ее носителя - колона (крепостного крестьянина) и его детей, которым он передает свои умения и навыки, в основном сельскохозяйственные. У крестьян большие семьи, неотделимые от земли, что позволяет получать прибавочную стоимость при их продаже. Сельскохозяйственные ремесла постепенно выделяются в отдельный вид деятельности, позволяющий особо искусным ремесленникам выкупать себя у феодала (одна из форм продажи). Освободившиеся ремесленники концентрируются в городах, многие объединяются в цеха, где формируются основы капиталистического способа производства.

В Западной Европе феодальное общество было распространено до появления протестанства в период Реформации. В США после обретения независимости также осуществился переход от рабовладельческого к феодальному обществу. Так как многие рабы-негры приняли христианство, а приток новых рабов сильно сократился.

Уже на этой стадии начинает формироваться пространство капиталистического рынка и соответствующая форма денег - бумажные деньги. 
3.

Капиталистическая: Д - Т кол.
Рс кач.

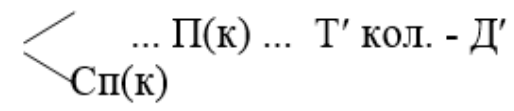

Поскольку товар обладает определенным фетишизмом, постольку деньги, являющиеся его эквивалентом, должны по своей форме соответствовать этот фетишу. Деньги принимают форму бумажных банкнот, ассигнаций.

За основу вида формул выбран вид формулы Маркса (где Д - денежный капитал, П - процесс производства в форме промышленного капитала), поэтому формула капиталистического обращения соответствует ей с учетом уточнений (соблюдается принцип преемственности, соответствия). Данная формула является квинтэссенцией «Капитала», где исследуются ее вариации.

Капиталист, как и констатирует теория Маркса, оплачивает труд после его совершения и вправе присваивать прибавочный труд, лишь его остаток по своему усмотрению оплачивая работнику (цель коммунистов - «справедливая» оплата этого остатка после присвоения основной части капиталистом - государством).

Коммунизм - одна из форм капитализма, далее которого коммунисты (сталинисты и последующие) экономически никогда и не продвигались, ограниченные марксистской политэкономией, лишь преобразовав капиталистический способ получения прибавочной стоимости в способ распределения прибавочной стоимости командно-административной системой. Впрочем, современные отечественные реформаторы также не сумели объяснить нового способа производства и получения прибавочной стоимости, следовательно, оставшись со старым.

4. Государственно-
капиталистическая: Д - Т кач.

Рабочая сила выведена за рамки экономической оценки как полностью оцененный параметр, поддерживаемый (обществом, государством) на достойном ей уровне в качестве основного товара, оплачиваемого в первую очередь, причем фактически оплачиваемого вперед (только так можно объяснить понедельную, а при высокой инфляции ежедневную зарплату наемных работников в ныне экономически развитых странах).

Требования к капиталистам оплаты труда наемных работников не ниже установленного государством уровня почасовой оплаты да еще с учетом инфляции более высоки, чем максимальные требования коммунистов по защите трудящихся, поэтому у них в странах государственного капитализма исчерпано пространство деятельности, а коммунистические партии в большинстве своем самораспустились.

Формулой отражается необходимость многообразия товара, а, следовательно, и его производителей, т.е. малых и средних предприятий. На базисе этого многообразия выстраивается система регулирования рынка.

Прибавочная стоимость делается уже не за счет эксплуатации рабочей силы, а на разнице стоимостей простого товара и составного. Механизм основан на производстве наукоемких изделий, стоимость которых высока из-за их новизны, что позволяет получать прибыли многочисленным фирмам, участвующим во всех стадиях производства сложного изделия, в том числе в проектировании, подготовке производства и т.д. Производственные отношения приобретают характер товар - 
товарных отношений между этими фирмами (такие отношения охватываются либеральной моделью).

На устаревшие модели изделий цены постоянно понижаются, поэтому необходим выпуск новых более качественных моделей изделий.

Внутри предприятий также моделируются товар - товарные отношения как основа управленческого учета (базирующегося на все той же теории предельной полезности), необходимого для оценки эффективности подразделений всех уровней и теперь невозможного без использования компьютеров из-за большого количества расчетов.

Начинается формирование пространства социалистического рынка, новых средств производства и соответствующей формы денег - электронной.

5 . Социалистическая: Д-Труд кол.
Т кач.

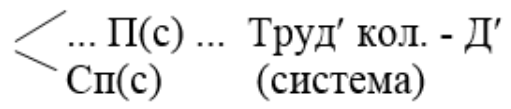

На данной стадии через произведенную биотехническую систему жизнеобеспечения непосредственно оценивается труд, причем делается это с помощью объективного механизма - рынка. Выполняется соотношение «каждому по труду», естественно, товара. Реализуется комплексный продукт, в котором товар самовосполнимая (автоматически реализуемая) составная часть. Другими составными частями могут быть предпродажное обследование, внедрение, сопровождение и т.д.

Новая форма денег - электронные деньги, используя современную терминологию, виртуальные настолько, насколько виртуален абстрактный труд. Средства производства становятся средствами труда.

Пространство социалистического рынка, как и всякое рыночное пространство, должно быть сформировано так, чтобы электронные деньги стали доступны каждому в полном объеме денежных функций.

В настоящее время нельзя обойтись без «новой» самостоятельной составляющей производства - информационной. Информационные ресурсы в производстве использовались всегда (в конструкторской, управленческой деятельности и т.д.), но наиболее отчетливо выделяются в последнее время в связи с созданием продукта, локализующего информацию и способного ее структурировать и преобразовывать компьютера.

Классические составляющие производства - природные (материальные) ресурсы, труд и капитал, участвуют в определении цены любого товара в виде природной ренты, заработной платы и прибыли. Новая составляющая участвует своей долей. Следовательно, необходимо ввести в политэкономию новую категорию - информацию в виде информационной ренты (современная производственная логистика, например, построена на анализе взаимодействия материального и информационного потоков, которые должны рассматриваться в отношениях одного уровня).

Составляющие производства могут, как известно, замещаться, причем любое замещение не произвольная операция, а экономический процесс. Так, замещая материальные ресурсы (требующие складирования) на информационные, современные предприятия реализуют процесс поставок по принципу «точно вовремя».

Информация своей достоверностью лишает товар фетишизма, который Маркс объясняет через аналогию с религиозным мышлением, а именно мышление создает информацию, следуя современной теории информации. 
Как и природная, информационная рента оказывает наибольшее влияние на макро уровне. Например, Россия получает природную ренту, продавая сырьевые ресурсы, но платит информационную, покупая за рубежом компьютеры, комплектующие для них и периферийные устройства (в том числе сетевые), а также программное обеспечение, начиная с операционных систем и заканчивая системами управления предприятиями (очень дорогостоящими). Баланс не в пользу России.

Обобщая вышеизложенное, можно утверждать, что от стадии к стадии увеличивается информационная составляющая и ускоряется оборачиваемость денежных средств, вкладываемых в производство. В результате все точнее оценивается труд.

\section{Современные цивилизации.}

С цивилизационной точки зрения мировые системы - далеко не самый удачный способ создать мировую цивилизацию, даже учитывая процесс глобализации.

С учетом приведенного выше анализа и расширения перечня современных цивилизаций [14] получаем (в скобках указаны доминанты):

1. Западная (Западноевропейская) - развивается экономически последовательностью формаций (стадий), попытки преобразовать ее в традиционную цивилизацию ведут к таким рецидивам, как фашизм (по Кара-Мурзе[3]).

2. Североамериканская (США) - в ее основе особенно ясно просматривается принцип взаимной независимости экономической, политической и идеологической составляющих, а также независимости властных структур - почти классическая формация, но молодая в цивилизационном смысле.

3. Восточная островная (Япония) - цивилизация традиционного типа с развитой экономикой (государственно-капиталистической).

4. Южно-Азиатская (Индия) - цивилизация с настолько сильной традиционной направленностью, что даже английская колонизация ее мало пошатнула.

5. Дальневосточная (Китай) - Китай ищет свой способ перехода к государственному капитализму, но это путь к СССР, хоть и специфичному (учитывая количество народонаселения - многократно более мощному).

6. Буддийская - традиционалистская.

7. Латиноамериканская (Бразилия) - типичный капитализм (столетней давности относительно западной цивилизации).

8. Исламская (мусульманская - арабские страны) - по Моисееву [7], давно миновавшая свой расцвет (во времена которого ее пытаются вернуть фундаменталисты).

9. Восточноевропейская - без лидера, да и цивилизация ли?

10. Океаническая (Австралия) - сильно разъединенная.

11. Африканская - протоцивилизация.

12. Евразийская (Россия) - проблематичная с точки зрения западной цивилизации, но как традиционная цивилизация имеет глубокие корни (по Моисееву [7]), как правовые, так и культурные.

\section{Российская метацивилизация.}

Как и многие современные цивилизации, Россия умела возрождаться, воспринимая новый способ производства, однако, никогда не укладывалась точно в рамки определенной формации, проявляя стремление развиваться традиционными цивилизациями с соответствующей формации адаптированной системой управления: 
- Протоцивилизация (рабовладение с моментами первобытной общины и феодализма). Древняя Русь практически не применяла производства как разделения труда по функциям. В пространственном (в территориальной части) плане Россию, видимо, следует считать преемницей великой евразийской цивилизации.

- Православно-крепостническая (феодализм с моментами рабовладения и капитализма). Всеобъемлющей идеологией православие стало в результате вестернизации. После отмены крепостного права способ производства почти соответствовал капиталистическому. Необходимо отметить, что в начале XX века западная цивилизация «уперлась» в ограничения, накладываемые капиталистическим способом производства, и Россия, переходя к капитализму, почти влилась в «русло цивилизации» (в интуитивном смысле опять же западной), уже почти не отделяя себя от нее (отсюда преждевременный ленинский вывод о существовании полноценного капитализма в России). Ощущая кризис роста этой цивилизации, общественная мысль начала поиск выхода из тупика. В ходе разразившейся мировой войны этот поиск перешел в практическую плоскость, став процессом, который возглавила наиболее активная партия - партия большевиков ввергшая Россию в «смутное время» гражданской войны, окончательно разрушив существовавшую российскую цивилизацию.

- Коммунистическая (капитализм с моментами феодализма и государственного капитализма). Командно-административная система - смесь феодального и гос. капиталистического регулирования (зарегулированы практически все сферы жизнедеятельности). Причем последний тип регулирования часто волюнтаристичен. Пример - коммунистическая система тарифов и окладов, которая якобы позволяла оценить вложенный в производство труд на любом уровне, реально же никак не способствовала повышению качественного состояния товара. Положительный аспект - производственная стандартизация.

- Новая Евразийская (прогноз - попытка построения гос. капитализма с моментами капитализма и социализма). Моменты капитализма неизбежны, так как в настоящее время отношения владельцев или «руководителей» предприятий (владельцев средств производства) с работниками этих предприятий (владельцами рабочей силы) еще не отрегулированы. С другой стороны, моменты экономического социализма позволят заглядывать вперед. Новая цивилизация может оказаться наилучшим способом (если не единственным) для достижения уровня производства государственного капитализма в России только при наличии всеобъемлющей идеи (например, идеи Качества Жизни для всех, основанной на духовной культуре народа). Система управления должна строиться на основе государственнокапиталистической системы регулирования (например, планово-договорная).

Процессы построения каждой российской цивилизации имеют много общих черт - не реформа, а новое содержание административно-территориального деления, властных структур и т.д. В конечном итоге все российские цивилизации преобразуются к традиционному виду, поэтому для реорганизации в современную цивилизацию наступает «смутное время», когда цивилизация распадается на отдельные независимые составляющие (экономическую, политическую и нравственную). Сам переход заключатся в преобразовании экономики, политики и нравственности (в виде идеологии) таким образом, чтобы создались условия для построения новой цивилизации путем интеграции составляющих, без чего есть опасность остаться в промежуточном состоянии. Например, известно, что Петр I, сколько мог, реформировал церковь на протестантский лад, формируя нравственную основу капитализма. В настоящее время российскому обществу быть может требуются 
классические элементы либеральной и христианской демократии, однако, если в западной цивилизации их поддержку берут на себя политические партии, то у нас этого не происходит из-за несоответствия направленности деятельности отечественных партий заявленной в названии миссии (например, ЛДПР) либо отсутствии таковой. Поэтому смена содержания в России проводится государством, которому приходится брать на себя и эти функции.

Радикально менять способ развития, помогавший «преодолевать» стадии западной цивилизации, - значит опять начинать с самого начала (одним из последних по времени примером тому служит Ичкерия (Чечня), никогда ранее самостоятельно с западной цивилизацией не контактировавшая, следовательно, начавшая с рабовладельческого способа производства).

Чисто производственно-рыночные варианты прохождения стадий являются слишком жесткими, если не жестокими, для России, а цивилизационные позволяют внести свою справедливость.

\section{Рыночные пространства и методы их исследования.} объекты).

Разные рыночные пространства содержат разные тела (товары: предметы,

Пространство рабовладельческого рынка содержит людей как тела - рабов. Феодальное пространство имеет такое же наполнение, но это уже другие тела, отличающиеся качественно - тела крепостных. Пространство капиталистического рынка содержит товары в смысле классической политэкономии, а государственнокапиталистическое - новые товары, включающие организационные услуги (поэтому для России актуальнейшая задача - производство новых качественных товаров и создание условий для их приобретения гражданами).

В постиндустриальном обществе, по идее Белла, главное - это доминирование теоретического знания, превалирование теории над эмпиризмом и кодификация знаний в абстрактные своды символов, причем решающими в процессе производства становятся отношения между людьми (совсем как у Маркса), пренебрегающими природой. Пространство, однако, составляют «неисчерпаемые» именно природные объекты, компоненты. Следовательно, постиндустриальное пространство должно содержать своды символов (в виде моделей), которые использует живая природа (аналогии между хозяйственной сферой и живой природой проводили еще Мальтус, Юм и др.). И в первую очередь должно быть наполнено пространство социалистического рынка моделями общества, социумов (новая сторона социализма) как частью моделей живой природы (что и составляет научный, синергетический аспект концепции устойчивого развития). Такое пространство согласуется с ноосферой как созданным людьми продолжением биосферы.

Современные общественные модели базируются на моделях производственных организационных услуг, однако и модели услуг должны быть приведены к экологическим общественным моделям, что невозможно без реорганизации обеих моделей, то есть, необходим переход к новой формации.

Касаясь методов исследования, необходимо отметить повышенную сложность общества по сравнению с неживой природой, изучаемой естественными науками и в первую очередь физикой. Это, однако, не означает отсутствия в обществе циклических процессов (некоторые экономические циклы описаны Кондратьевым [4]), которые могли бы стать основой процессов волновых. Известно, что делалось множество попыток прямого переноса методов квантовой механики (из-за недостаточности старых методов, например, статистического, берущего начало от описания идеального газа, то 
есть, от множества одинаковых невзаимодействующих и хаотичных частиц) на описание общества (по примеру смитовской кальки с классической механики), оказавшихся неудачными.

Более надежно опираться на логический вывод основного уравнения квантовой механики, найденный Терновым и Соколовым [10] и определяющий, что уравнение Шредингера представляет собой систему трех уравнений. Первое - закон сохранения энергии на орбите, второе - общее волновое уравнение колебания среды, третье соотношение для длин волн (такой симбиоз не совсем отвечает основам физики, что никак не мешает его адаптации для описания социальных процессов).

В нашем случае средой может быть рыночное пространство, определяемое производством, а возмущающее движение - развитие цивилизации (в простейшем случае - по кругу в платоновско-аристотелевом смысле).

\section{Устойчивое развитие.}

Жесткие условия к уровню экономического развития, предъявляемые к странам, входящим ныне в единое экономическое пространство Западной Европы, свидетельствуют о стремлении западной цивилизации консолидироваться на стадии государственного капитализма. На одной стадии в рамках современного общества легко согласуются взаимоотношения, почти равноправные, с США, Японией. Иное дело Россия, застрявшая на стадии капитализма, отсюда разница в уровне жизни людей и т.д.

Что касается экономического социализма, то пространство, подходящее для социалистического рынка может быть сформировано и уже формируется через глобальные компьютерные сети. Причем современная тенденция направлена не только на использование сетей типа Интернет/интранет для продажи, но и для управления данными о продукте на протяжении всего жизненного цикла, начиная с маркетинговых исследований и проектирования, заканчивая утилизацией.

Лидер этого процесса - США, развивающие сетевую экономику как сегмент регулируемого капиталистического рынка. Однако для того, чтобы продукт хорошо продавался через глобальную сеть, он должен быть настолько качественным товаром, чтобы покупатель, выбирая его по изображению на экране компьютера, был уверен в полном соответствии картинки и приводимых характеристик реальному продукту и его свойствам. После бурного подъема сетевой экономики выяснилось, что в рамках капиталистических отношений этого достичь не удается, следовательно, мы имеем дело совсем с другим рынком, а не только с так называемым информационным пространством.

Выводы:

Концепция устойчивого развития на основе государственного (учитывая глобализацию - мирового) капитализма бесперспективна. Постиндустриальное или информационное общество таким способом недостижимо, так как ведет к усилению нагрузки на природу.

Концепция должна быть основана на последовательном, бережном по отношению к природе и человеку (но не организованному криминалу, использующему способы производства отживших формаций) движении от низшей формации к высшей (от одной цивилизации, реализующей культурно приемлемый способ взаимодействия составляющих производства и общества, к другой цивилизации) по направлению к постиндустриальному обществу. 
У России еще достаточно природных ресурсов не только для перехода к государственному капитализму (к высокотехнологической индустриализации), но и для ускоряющегося стадиального развития, особенно при применении сберегающих технологий.

\section{Глава 2.}

\section{Производство в синергетическом аспекте.}

Характерный для современной России обвальный износ основных фондов подготовлен упадком производства за последние 15 лет. Превышение их ежегодного износа $(4 \%)$ над созданием новых $(0,5 \%)$ составляет около $3,5 \%$, что привело к критичному износу порядка 70\% основных фондов в 2003г. (тенденция выбывания сохраняется - около 10\% за 3 года и к 2009 г. выбывание составит 90\%, следовательно, останутся только новые фонды, несвязанные в системы, то есть произойдет окончательный развал систем жизнеобеспечения). Выбывающие основные фонды были созданы трудом коммунистической цивилизации - интенсивным производственным трудом, организованным высокими цивилизационными характеристиками (коллективизм, образованность, изобретательность...).

За эти годы словно «подзабыли», что созидательной основой общественного богатства является производственный труд, увлекшись перераспределением собственности (только не в пользу народа).

Производство определяется материальной культурой (изначально присущей производственно-рыночной западной цивилизации) и формируется по способам. Способ производства взаимосвязан со способом получения прибавочной стоимости (зарабатывания денег в условиях конкуренции на рынке) так же, как производительные силы связаны с производственными отношениями. Основой всех демократических свобод для материальной цивилизации является экономическая свобода в рамках определенного способа получения прибавочной стоимости.

На применение единого способа получения прибавочной стоимости требуется общественное (национальное) согласие, в том числе и от работников, претендующих на адекватную оплату своего труда (при соответствующем уровне средств производства, в том числе машин).

Один способ производства сменяет другой не произвольно, а последовательно в соответствии со стадиально-формационной парадигмой. В этой парадигме вся история западной (и не только) цивилизации может быть представлена как последовательное увеличение эффективности труда (классический пример товарного производства фабричное производство булавок, в десятки раз более эффективное, чем изготовление в мастерских, где каждый работник выполнял все операции). Производительность труда от стадии к стадии резко возрастает. Общественно-экономическая оценка сущности каждой стадии производится через универсальный инструмент - деньги соответственно изменяющие свою форму. Освоение определенного способа производства возможно в цивилизационном варианте с присущими культурными особенностями (синергетическая вариантность).

Для материального развития любому государству необходимо остановиться на определенном способе производства в той мере, которая позволит производству заработать.

Производство - наиболее мощный макроэкономический фактор. 
Так как материальная (западная) цивилизация основывается именно на материальной культуре, то приемлемый способ производства и получения прибавочной стоимости на рынке является определяющим не только для экономики, но для политики и всей общественной жизнедеятельности. Такой же подход (от материальной культуры) применял Маркс для описания в «Капитале» капиталистического (и только) способа производства и получения прибавочной стоимости (в том числе капитализма, который существует ныне в России и именуется «диким» за высокую криминализированность и коррупционность). Этот же способ производства, но в форме единого государства-завода был реализован коммунистами, но не в рыночном, а в цивилизационном варианте (недостаток рыночности сказался и привел к упадку из-за рыночного фундаментализма и стихийности).

Цивилизация, кроме прочего, еще и система возможностей и ответственности (невозможен беспредел), в которой следует учитывать фазу развития (подъем, спад или др.). Так, коммунистическая цивилизация (СССР) распалась, а, например, новая турецкая или китайская, использующая тот же самый способ производства, на подъеме.

Совсем иной способ производства и получения прибавочной стоимости распространен и поддерживается государственными институтами в развитых странах как государственно-капиталистический (применение единого способа получения прибавочной стоимости наиболее последовательно применяется в США и прививается с детства). Следовательно, сформировалась новая стадия в развитии западной цивилизации, для которой формула воспроизводства будет отличаться от формулы Маркса (также должны отличаться формулы для рабовладельческого и феодального способов производства). Новый способ производства основан на перманентном увеличении качества и новизны товара, что позволяет вывести рабочую силу за рамки экономики, оплачивая ее как реальный (а не специфичный) товар полностью и в срок.

Из всех составляющих нового способа производства в последнее время наибольшее развитие получила информационная составляющая, развеивающая всякий «товарный фетишизм» и сделавшая управление наукой (в «диком» капитализме управление - это искусство). Широкое распространение компьютерных систем проектирования (CAD/CAM/CAE), управления производством (ERP), отслеживания продукта на протяжении всего жизненного цикла (PDM/PLM), а также их интеграция позволяет формировать единое информационное пространство предприятия и получать мощный экономический эффект за счет ускорения выпуска новых изделий, управления проектами, управленческого учета и т.д.

В цивилизационной форме (ориентация на собственные силы при максимальном замещении эксплуатации высокоэффективным цивилизационным трудом) государственно-капиталистический способ производства реализован, например, в Японии. А в Англии новый импульс развитию дала государственная политика «капитализма для всех», реализованная правоконсервативным тэтчеровским правительством (которое использовало принцип сдержек и противовесов для уменьшения влияния факторов, противодействующих реализации идеи, в отличие от ельцинского способа применения этого принципа - для нейтрализации вообще всех идей ради сохранения собственной власти - приведшего к неэффективной производственной политике).

В отличие от государственного, рыночный капитализм в любой другой форме (олигархической, номенклатурной, религиозной ...) не способен создать современные производственные отношения и, следовательно, поддерживать производительные силы на уровне более высоком, чем они были, например, в США в конце двадцатых годов прошлого века. Можно утверждать, что основные российские производственные фонды будут падать приблизительно до того уровня, а в результате подвергнутся разрушению 
многие системы не только производственного, но и жизненного обеспечения (пенсионная, медицинская, ЖКХ...).

За последние годы высокие цивилизационные трудовые характеристики российского народа растворились в непроизводственных формах труда, например, на небольших приусадебных участках, способных как-то прокормить семью, но на порядок и более уступающих в производительности западным фермерским хозяйствам.

\section{Производство и глобализация.}

Современная глобализация сулит как выгоды, так и угрозы.

Угроза деградации - со стороны феодальных (которые называют странамиизгоями или государствами-террористами) либо тех государств, которые ранее производственным трудом не занимались, а получив такую возможность, неизбежно начали с рабовладельческого (рабозахватнического) способа производства, который требует «добывания сырья» - захвата рабов путем похищений, вооруженных нападений и террора, а также организации рынка рабов (например, в Чечне) для их продажи (выкуп - одна из форм продажи). Существует также внутренняя угроза со стороны преступных сообществ, использующих худшие способы наживы, а также со стороны апологетов имперской политики любыми средствами.

Угроза задержки развития - религиозный капитализм. Многие религиозные организации достаточно «набрались» протестантской этики, чтобы идеологически способствовать освоению капиталистического способа производства. Как, например, в Южной Америке под воздействием католичества, в Израиле - иудаизма, в Турции мусульманства (нефундаменталистского). Православная церковь, каким товаром только ни торговавшая в последнем десятилетии прошлого века, также освоилась с капитализмом (чего от нее добивался еще ПетрI). Однако в Российской Федерации исповедуются и другие религии, например, мусульманская, которая, по примеру Турции, способна самостоятельно поддерживать капиталистический способ производства и получения прибавочной стоимости в собственном регионе.

Следовательно, угроза задержки развития может представлять угрозу сохранения экономической отсталости от развитых стран, угрозу устойчивости как политической, так и экономической из-за высокой доли теневой экономики и большой разницы в доходах населения.

Гораздо меньше угроз и больше выгод (выход на единый стандарт отношений с развитыми странами и т.д.) содержит развитие способом государственного капитализма (возможно, в цивилизационном варианте или в варианте метацивилизации, способной к поэтапному развитию).

Переход России к государственному капитализму тормозится не только экономически, но и политически. Политические партии, такие как либеральнодемократическая, правых сил и другие не способны (и не хотят) поддерживать соответствующую идеологию, довольствуясь дивидендами от своих громких названий, получаемыми во время выборов в виде дополнительных голосов избирателей (общественные движения вообще не имеют никакой идеологии, так как не способны создать основу идеологии - теорию, без которой невозможно проведение скольконибудь эффективной созидательной политики). Кроме того, необходима поддержка единого способа производства и получения прибавочной стоимости со стороны всех ветвей власти (в виде создания соответствующих институтов, новой налоговой политике, неотвратимого наказания за применение других способов производства и т.д.). Тогда переход к государственно-капиталистическому способу производства позволит резко увеличить государственный бюджет и повысить уровень жизни 
большинства населения и начинать его нужно с высокотехнологической индустриализации.

При дефиниции государственного капитализма как отдельной стадии становится возможным дать определение глобализации (такое определение отсутствует как в политологическом, так и в других подходах описания процессов современности, поэтому и специалисты по глобализации в России отсутствуют, что для нее становится фатальным).

Итак, глобализация есть распространение государственно-капиталистического способа производства и получения прибавочной стоимости при расширении до мирового уровня капиталистического рыночного пространства (в первую очередь регулируемого рынка природных ресурсов, без которого может рухнуть вся капиталистическая система).

Апологетами глобализации предполагается, что все смогут освоить государственный капитализм, однако, как показано выше, это возможно в отношении только тех государств, которые уже прошли капиталистическую стадию. Противники же глобализации понимают, что остальные будут всячески ей сопротивляться потому, что зарабатывать новым способом пока не способны (кроме продажи «богоданных» ресурсов, например, нефти). Сопротивление может выражаться в попытках сохранить (и, по возможности, расширить) тот рынок и способ получения прибавочной стоимости, который освоен (для докапиталистических обществ такой способ может быть связан с работорговлей и ее культурой - террором).

Переход к государственному капитализму усложняется еще и тем, что нет единой методики такого перехода на международном уровне, где каждая структура выпячивает и заботится только о собственной составляющей (как МВФ - только о финансах), тем самым только затрудняя дело.

России нужно государство, которое сможет провести высокотехнологическую индустриализацию и поддерживать государственно-капиталистический способ производства, иначе она отстанет навсегда, так как точка бифуркации уже близка.

Необходимо остановить тенденцию развала российского производства, тем более что она ведет к экономическим потрясениям, случившимся и на следующий год после тридцати процентного выбывания основных фондов (1992г.), и после пятидесяти процентного (1998г.). 2004-й год также стал кризисным (банковский кризис и рост цен в производственном секторе). Глобализация показывает неспособность российской элиты преодолеть неоколониализм 90-х годов, превративший Россию в сырьевой придаток, дать стимул к развитию производства и построению цивилизации (с непротиворечивыми законами, составляющими правовую систему). Ведь именно правовая система является исторической основой российской цивилизационности, так как православие - право славить (для сравнения: виноделие - вино делать), интерпретация «правильно славить» (бога) появилась позднее и связана с отменой древнерусской правовой системы, описанной в «Русской правде». Но старые правовые системы не годятся и даже мешают, могут привести к политическим рецидивам, например, неофашизму (Германия не смогла в 20-х годах XX века построить государственный капитализм и получила феодальный рецидив - фашизм, который нес народам новое крепостничество).

Основное противостояние начала XXI века - между капиталистическим и докапиталистическим обществами, грозящее крупнейшими катаклизмами. Самый лучший выход (если не единственный) - в движении вперед, к постиндустриальному обществу (индустрия - товарное производство), где производимым продуктом будут уже не товары и даже не товары, сопровождаемые услугами, а технические системы жизнеобеспечения, построенные в соответствии с законами живой природы и 
реализуемые на рынке нового типа, пространство которого может (и должно) соответствовать ноосфере.

\section{Глава 3.}

\section{Гражданское общество, демократия и рынок}

В настоящее время Россия позиционируется по уровню западной цивилизации с отставанием в 80 - 100 лет по структуре производства и управления (бизнеса), соответствующего капиталистическому способу производства (первичному) в Европе и США позапрошлого и начала прошлого века (исследованному Марксом в «Капитале»). С тем же отставанием идут политические партии: коммунисты - левые производственники-марксисты, а правые - консерваторы (хотя должно быть все наоборот), выступающие, следовательно, за возврат к феодальному обществу царской России (для них на столетие вперед все открыто, поэтому наука сто лет не нужна и была развалена в девяностых годах). Центристы поддерживают первичный рыночный капитализм, стабилизируя отставание.

Пока Россия смотрит назад, а не вперед (по утверждению экспертов, например, К.К. Мельника, создававшего вместе с де Голлем госкапитализм во Франции), что грозит отставанием навсегда.

Провозгласив стихийный рыночный фундаментализм и полную свободу бизнеса, правые реформаторы возродили в стране не только капиталистический, но и рабовладельческий рынок (торговля людьми, в т.ч. получение выкупа), особенно развившийся в Ичкерии, а также феодальные производственные отношения (зарплату феодал не платит, считает ресурсы своими и требует с них арендную плату). Народ отказал правым в поддержке на последних выборах в парламент, но они надеются на имперский (по Чубайсу) реванш.

Необходимо определиться с гражданским обществом, иначе его развитие невозможно.

Гражданское общество западного типа - общество, в котором существует согласие собственников на применение единого способа производства и получения прибавочной стоимости (порождается синергетический эффект) - основа формации.

Структура гражданского общества собственников (в т.ч. чиновников) и его демократии:

Рабовладельческое - 2,5-5\%\% (в Др.Риме количество рабов в 30-40 раз превышало количество свободных граждан).

Феодальное - 10-15\%\% (например, в царской России, где крестьяне, в основном крепостные, составляли около $85 \%$ населения).

Капиталистическое - 25-30\%\% (Англия XVIІв.- начала ХХв. и др.).

Госкапиталистическое - более 50\%, но далеко до 100\% (впервые гражданское общество собственников, например в США второй половины ХХв., стало демократическим и в цивилизационном смысле, т.е. властью большинства).

На каждой стадии свой уровень жизни, то есть первичный капитализм никак не способен создать в общероссийском масштабе уровень жизни развитых госкапиталистических стран.

Следует заметить, что и США, продвигая демократию и гражданское общество собственников (рыночная демократия), не принимают в расчет, что докапиталистические цивилизации стихийным образом способны не более чем на рабовладельческий рынок (в культуре которого преобладает террор, а собственность 
есть священное право бандитов). Ситуация в корне отличается от послевоенной, середины прошлого века, когда возрождались государства, прошедшие стадию капитализма и готовые к государственному капитализму (западная Европа, Япония).

К сожалению, в 90-х в России строилось не госкапиталистическое, а симбиоз первых трех гражданских обществ, причем каждое с соответствующим ему чиновничеством, отсюда количество чиновников резко возросло. С начала нового века власть пробует бороться с докапиталистическими способами производства, однако, без необходимой синхронности всех ветвей. При отсутствии институтов госрегулирования (впервые созданных Ф.Рузвельтом в США) перейти на новую стадию невозможно, тем более исходя только из экономических процедур, например бюджетирования.

Другая структура у цивилизаций (традиционных), многие из которых строятся по своеобразному, но весьма демократическому принципу суверенной демократии, сплачивающему общество в первую очередь на принципах общественной собственности (например, социализм как цивилизационность). Здесь гражданское общество состоит из поддерживающих правовую систему и работающих в первую очередь на благо общества.

Однако есть опасность смешения цивилизационных материальных культур прошлого (что и произошло в России): древнерусское ушкуйничество, древнееврейское поклонение золотому тельцу (деньгам, полученным любым способом), византийская коррупционность, плутократия, олигархия ..., одним словом «дерьмократия».

Развитию способствует согласованность цивилизационности и формационности на новом уровне, способная создать синергетический эффект бурного развития. Несогласованность может привести к развалу (СССР плохо соответствовал формации из-за почти полного отсутствия рынка, а современная Россия не является цивилизацией, в частности, из-за крайней раздробленности общества).

Бывшим союзным республикам (кроме прибалтийских) придется еще проходить капитализм, а если развалится Россия, то и ее частям. России нужна двухпартийная (в идеале) политическая система с соответствующими идеологиями: формационной и цивилизационной (похожая во многих развитых странах, например, демократическая и республиканская или либерал и социал демократические). Причем при отсутствии идеологии у партий (партии, не имеющие идеологии как современной системы ценностей, не доступны пониманию не только народа, но и специалистов - теневые партии), таковыми может обладать, например, общественное движение. Но и двухпартийная политическая система не гарантирует перехода к современному госкапитализму (в США она существовала и при первоначальном капитализме столетней давности и ранее).

Глобализация показала неспособность российской политической и экономической элиты дать стимул к развитию производства (ни одно крупное предприятие не заработало лучше после приватизации, что ставит под большое сомнение тезис о необходимости такого частного собственника). Но и сама глобализация забуксовала (американская даже после военных побед не может дать странам эффективного способа развития, европейская практически достигла своих пределов), а число антиглобалистов (как внешних, так и внутренних) выросло до числа, способного остановить сам процесс. К тому же глобализация никак не уменьшает напряженности в мире и не способствует решению задачи уменьшения терроризма. Истоки последнего до сих пор плохо идентифицированы, словно урок Ичкерии не показал, что терроризм напрямую связан с работорговлей и, более того, является культурной обстановкой рабовладения (как и в Древнем Риме), считавшимся прошедшей стадией в развитии западной цивилизации, переход от которой к 
капитализму для докапиталистических обществ арабских стран отнюдь не произойдет сам собой.

\section{Синергетический рынок}

Гражданское общество собственников неразрывно связано с экономической демократией и, следовательно, с рынком.

В синергетическом аспекте рынок - диссипативно созданные структуры (в западной цивилизации - только в экономике), самоорганизующиеся в соответствии со способом производства; способ производства соответствует способу получения прибавочной стоимости на рынке, а его базисный элемент для стадии является синергетическим параметром порядка (способ производства и получения прибавочной стоимости). Параметр порядка способен к преемственному изменению, что является сутью процесса развития (поэтапная система реализует стохастический детерминизм).

Следовательно, можно говорить о синергетическом рынке [16] как нестихийно самоорганизующейся системе (в которой может быть описан системно-синергетически инновационный процесс, не представленный в экономической науке), обладающей свойствами необратимости по отношению к отжившему, например, рабовладельческому рынку и флуктуационного развития (для многообразия рыночных ниш) по направлению к постиндустриальному глобальному рынку.

Тогда в синергетическом аспекте могут быть рассмотрены макроэкономические параметры.

Ценообразование на рабовладельческом рынке строится от стоимости раба либо при феодальном строе - крепостного. На капиталистическом рынке ценообразование сначала строится от стоимости товара как предмета, а при государственном капитализме от стоимости сложного товара, включающего услуги. Если при госкапитализме цена товара увеличивается при увеличении его качества в широком смысле (качеств), то при обычном (первоначальном) капитализме, наличествующем в современной России, повышение цены товара зависит только от его наличия. Постиндустриальный рынок - рынок с ценообразованием от синергетических (высокотехнологических) систем жизнеобеспечения.

Рыночной экономике свойственна инфляция, причем возможно наложение инфляций для отставших в развитии. Так инфляция для современной России складывается из инфляции собственной - капиталистической и глобализированной госкапиталистической (долларовой и евровой из-за внутреннего хождения этих валют, a также у.е.), а в результате инфляция (рублевая) деградационная - более 8\% (накладывается еще известная инфляция издержек из-за износа основных производственных фондов). Во времена разгула рыночного фундаментализма начала 90-х годов накладывалась еще и инфляция ранних способов получения прибавочной стоимости, что привело к обвалу рубля.

Способы производства соответствуют дополненной стадиально-формационной парадигме. Их эффективность различна, что проявляется в многократной разнице в производительности труда, а, следовательно, валового продукта (сложность продукта повышает занятость населения). Переход от стадии к стадии осуществляется скачком (катастрофа по соответствующей теории). Однако существует возможность некоторого сглаживания скачка (но это не происходит линейно, как считают глобалисты).

Немаловажно пространственное представление рынка. Рабовладельческое рыночное пространство - плоское (в соответствии с представлениями субъектов рынка о пространстве), капиталистическое - обладает кривизной, но не может быть замкнутым; охватить планету должно другое рыночное пространство (постиндустриальное, информационное, ноосфера). 
Т.о. глобальное пространство инфосферы (и ноосферы) может быть построено и освоено как рыночное, соответствующее ей по охвату (синергетический рынок переходный на высшую стадию, в котором действуют уже не экономические, а синергетические эффекты [16], учитывающие инновационные процессы), но с новым способом производства как «для себя» (следующий 5-й уровень структуры).

\section{Точки бифуркаций}

Россия на грани бифуркаций, так как материальная культура "дикого" капитализма, когда наработанное ранее использовалось приватизаторами как ресурс или потенциал (практически без амортизационных отчислений), подходит к концу из-за исчерпания этого ресурса. Кроме того, как и США в 1929 году, практически неконтролируемая законами свобода бизнеса (спекулировать) доведет до кризиса.

Первая точка бифуркации - возможного развала России (в соответствии с политикой США) и новых форм первоначального капитализма (как для рыночной формы потребовался развал СССР) на территориях, которые не смогут или не захотят уходить от капитализма (см. К.Маркс, «Капитал») с аморфными политическими партиями, создаваемые политиками «под себя» и не утруждаемые современной партийной идеологией (Россия, Израиль, страны Латинской Америки...).

Либо преодоление капитализма - переход к новой материальной культуре, но необязательно к лучшей.

Вторая точка - феодальный рецидив (одной из форм которого был фашизм), если не будет остановлена тенденция к развалу производства, то немногое, созданное за последние годы, может быть использовано как ресурс для возврата к докапиталистическому, построенному исключительно на производстве сырья и вооружений, обществу (соответствующая аристократия уже восстановлена). Резко уменьшится уровень и продолжительность жизни народа до состояния позапрошлого века; тогда неофеодальным государством с ядерным оружием раньше Ирана может стать Россия и этот вариант вполне вероятен и опасен для всего мира.

Либо госкапитализм - цивилизационный, даже метацивилизационный, обеспечивающий занятость и уровень труда и жизни населения (при оплате труда не менее 3 евро в час, иначе, по утверждению ООН, работник выпадает из современного производства и общества), способствующий его увеличению. Это достижимо при объединении усилий, например, с Белоруссией и Казахстаном (с привлечением их опыта в преодолении преступности, коррупции и т.д.) для построения госкапиталистической материальной культуры [16] евразийской метацивилизации (основанной на развитой правовой системе и прогрессе).

\section{Глава 4.}

\section{Физическое представление информации}

(к информационно-синергетической натурфилософии)

На каждой стадии развития западной цивилизации господствует то мировоззрение, которое определяется натуральной философией и способствует материальному развитию. В XVI - XIX веках формировалось и превалировало механистическое мировоззрение, в XX веке - энергетическое, а XXI век видится как информационный. Шире того, «информационная волна» будет весьма кардинально отличаться от сельскохозяйственной и промышленной (по Тоффлеру). Однако первая 
попытка «оседлать» информационные технологии, бурно начавшись в конце прошлого века, закончилась большим разочарованием в сетевой экономике (американские инвесторы и политики спешно вернулись к «традиционным ценностям» - нефти и оружию, перегревая соответствующие рынки - результатом чего стало начало новой войны в Ираке).

Экономическое развитие западной цивилизации основано на определенных закономерностях и первая из них - необходимость научного подхода к определению сути основного ресурса, считающегося неисчерпаемым. Так была определена вещественная суть сил (в механике и других разделах физики), затем физически же была интерпретирована энергия (законы сохранения, превращения и т.д.), что способствовало увеличению научного познания предмета, давая толчок его практическому использованию в производстве.

Новый толчок способно дать физическое определение информации необходимое условие познания (в том числе живой природы и социума) и развития в усложняющемся мире (информация - мера активности и сложности системы или объекта и способ разрешения неопределенности его развития).

Кроме того, гуманитарное направление в науке становится возможным в том случае, если для него есть предпосылки в естественных науках, в первую очередь в физике. Так в «Математических началах натуральной философии» Ньютона доказывается возможность применения геометрического силового метода не только в естественной, но и в любых областях действительности (отсюда и появление механистического мировоззрения). Позднейшее энергетическое мировоззрение утвердил энергетический императив Освальда (критиками императив не был опровергнут, а только дополнен различными составляющими, относительно приложения к обществу, например, трудовой и монетаристской) в совокупности с достижениями физики начала прошлого века в описании энергии (E=hv, $\mathrm{E}=\mathrm{mc}^{2}$ и дp.). Подобным образом может быть утверждено информационное мировоззрение, способное привести общество к новому анимистическому альянсу (единству с живой природой) в условиях критического убывания материальных и энергетических ресурсов.

Переход от современной физики к физике живой природы затруднен отсутствием представления, которое позволило бы учитывать множественные взаимосвязи и взаимодействия между элементами (объектами, системами) живой природы путем обмена веществом, энергией и информацией. Как ни парадоксально, но исходя из наиболее общих, парадигмальных представлений, можно уменьшить размерность взаимосвязей до обозримого уровня и подойти к решению этой проблемы, выделив информационную составляющую.

Наиболее разносторонне изученная часть живой природы - человеческая популяция, которую можно описывать, минимизируя до полного исчезновения личностный фактор, а тогда она практически ничем не будет отличаться от любой другой популяции живой природы. Таким образом, путь к физике живой природы способен лежать через физику общества как ту часть социальной действительности, которая наиболее поддается формализации. Например, известно, что в построении политэкономии Маркс использовал методы, которые только появились в то время в физике, а именно для цикличности процесса воспроизводства использовал понятие цикла, сформулированное в термодинамике, и как физические рассматривал производственные отношения (эти вопросы осветил в работе «Введение в философию» М.К. Мамардашвили). Маркс, однако, не мог определить их информационную природу 
при отсутствии сколько-нибудь научного понятия информации, появившегося только в середине XX века.

Со времен Маркса произошли большие изменения как в физике, так и в описании социума, где широкое развитие получила цивилизационная парадигма, а стадиально-формационная парадигма ныне очутилась в «опале» (американцы, например, ее практически игнорируют). В таких условиях наиболее эффективный путь - синтез парадигм на системной основе. Такой путь позволяет согласовать трудовую теорию стоимости и принцип (теорию) предельной полезности в рамках теории западной цивилизации (основа которой - материальная культура) и выделить высшую современную стадию - государственно-капиталистическую, на которой находятся экономически наиболее развитые страны (в то время, как Россия остановилась на стадии капитализма, хорошо описываемого марксистской политэкономией). А так как и другие цивилизации экономически развиваются поэтапно (стадиями, но часто в собственном цивилизационном, а не чисто рыночном варианте), то наиболее наглядно эта закономерность проявляется не внутри ядра западной цивилизации (Западная Европа), а на примере других цивилизаций. Так США, являющиеся ныне центром молодой Американской цивилизации, гораздо позже Западной Европы, но проходили все теже стадии развития, определяемые производственно-рыночной формацией (показанные в авторской работе «Основы универсальной социально-экономической теории»):

Рабовладельческая: ок. 1701г. - 1775г. (государственность еще весьма размыта).

Феодальная: 1783г. - 1857г. (с предварительным переходным периодом 1775г. 1783г., включающим войну за независимость).

Капиталистическая: 1865г. - 1939г. (с переходным периодом 1857г. - 1865г., начавшимся депрессией на севере и включающим гражданскую войну).

Государственно-капиталистическая: 1947г. - 2021г. (с предварительным переходным периодом 1939г. - 1947г., включающим вторую мировую войну и выход из нее на новую стадию).

Этапы равны по времени и длятся 74 года, а продолжительность переходных периодов равна 8 годам (все с точностью до замкнутого цикла - года). Последний переходный период (смутное время) начнется с 2021 года (за десятилетие до этого цивилизационный кризис, как и в 1929г., на более ранней стадии). Основной вопрос что собой представляет следующая постиндустриальная стадия? Ее можно назвать стадией рыночного социализма, производственные отношения которого еще более отличаются от описанных Марксом в «Капитале» (марксисты, в какие бы демократические одежды не рядились, уверены, что прибавочная стоимость получается исключительно за счет эксплуатации рабочей силы).

Попытка сохранения собственного государственного капитализма путем его расширения до мирового уровня (глобализация с контролем за природными ресурсами) пока удерживает экономику США от развала, но создает все больше проблем, так как невозможно привести некапиталистические страны сразу к государственному капитализму (перепрыгнуть через стадию).

Весь приведенный процесс можно представить как синергетическую волну. Следовательно, квантование наблюдается не только в микромире, а волна, имеющая временной характер и учитывающая как внутренние, так и внешние факторы, является информационной. Информационная волна американской материальной культуры выглядит как классическая (с постоянной длиной волны).

Другой пример - способ культурного развития российских цивилизаций: 
Рабовладельческая : ок. 389 г. - 1605 г. (1216 лет), берущая начало от Византии и закончившаяся Борисом Годуновым (с предварительным переходным периодом 381 г. - 389 г., когда «православие» стало самостоятельным).

Феодальная : 1613 г. - 1917 г. (304 года), крепостническое правление династии Романовых (с переходным периодом 1605 г. - 1613 г., включающим первое смутное время).

Капиталистическая : 1925 г. - 2001 г. (76 лет), коммунистическая цивилизация капиталистического способа производства в рамках одного «социалистического» завода-страны, начавшаяся сталинской индустриализацией (с предварительным переходным периодом 1917 г. 1925 г., включающим революцию, гражданскую войну и НЭП).

Коммунистическая цивилизация закончилась десятилетием упадка в 2001 году, так как именно тогда коммунисты лишились присутствия в российском правительстве и большинства в законодательной ветви власти. С того же года началось новое смутное время, в течение которого будут критически выбывать основные производственные фонды и многие системы жизнеобеспечения. Возможна некоторая стабилизация в виде религиозного капитализма (если православие дорастет до протестантской этики), однако он не будет развиваемым (латиноамериканский вариант), так как плохо восприимчив к достижениям науки и высоким технологиям (сырьевая направленность экономики), а рынок, вместо того, чтобы поднимать экономику, забрался в политические, властные и другие структуры (коррупция, рэкет...). Только государственный (в «западном» смысле) капитализм (что соответствует и рекомендациям американских ученых) способен вывести страну к развитию с применением научно обоснованного планирования. Тогда новая цивилизация цивилизация качества жизни, а ее система управления может строиться на основе системы управления качеством продукта, начиная от законов и заканчивая товаром (количественно-товарная система развалилась, но и система только на основе экономических принципов, в первую очередь одногодичного бюджетирования, привела к дикому капитализму и снижению уровня производства), - может планироваться на 2009г. - 2028г., но предварительно культурный вектор должен сменить направление с разрушения на созидание.

Опоздание с преобразованиями чревато катаклизмами (революциями и войнами), в то время как передовые процессы могут быть эволюционными.

Продолжительность российских переходных периодов равна 8 годам (как и у американцев), но каждый новый этап короче предыдущего ровно в 4 раза. Такая волна отличается от классической тем, что у нее кратно по времени изменяется длина волны (ускоренное развитие). Процесс построения и смены российских цивилизаций может быть представлен как информационный (с обратной связью) волновой процесс смены материальной культуры с византийской на западную.

Кратность информационной волны может быть равной 2, что показывает анализ (предварительный) поэтапного развития Японской цивилизации (отличительная черта которой - собственная правовая система). Волна с нулевой кратностью вырождается в цикл и соответствует, например, организму (смертному).

Сохраняющееся (закон сохранения) соотношение, определяющее кратность, может быть представлено как суть информации (информация есть мера активности), то есть информация пропорциональна кратности волны. Тогда, например, абсолютное (хронометрируемое) время есть непрерывная (идеальная) информация с единичной кратностью. Относительное же время как собственное время сложного объекта может поддаваться изучению и влиянию. 
Кратная волна взаимодействия, являясь сходящейся волной, поэтапно выполняет информационную задачу разрешения неопределенности. Следовательно, в квантовой механике может быть использована информационная волна (для определения коллапса волновой функции, что позволит отказаться от изначально критикуемого вероятностного подхода). Новый подход позволит приступить к научному описанию взаимодействий (основное свойство информации - сохраняться у всех взаимодействующих сторон) и восполнить теоретический вакуум не только в физике, где необходим новый подход для осуществления, например, управляемого термоядерного синтеза, но и в материаловедении и метеорологии, в медицине и биологии, в экономике и т.д., везде, где используется стадиальность (поэтапность), но на практике очень несистемно.

Существует связь количества информации и энтропии (сумма информации и энтропии - величина постоянная). В стационарных состояниях внутреннее производство системой энтропии компенсируется отрицательным потоком (по Пригожину - внешним) энтропии, который в сложной системе способен складываться в информацию (энтропия аддитивна). Стационарным состояниям свойственна самоорганизация (в экономике стационарное состояние определяет диссипативные рыночные структуры).

Вышеприведенные примеры описывают процессы (или функциональную составляющую информации). Однако, принимая во внимание гипотезу о структуре как «застывшей» информации, можно утверждать, что одна из последних загадок Солнечной системы - загадка кратности средних расстояний между планетами, разрешается информационным взаимодействием (для больших планет кратность равна 2 с минимальными, допустимыми природой отклонениями).

Новое определение стационарного состояния позволяет понять, что простейший атом - атом водорода - достаточно хорошо описывается боровской моделью потому, что представляет собой равновесное состояние. Более сложные атомы описываются энергетической моделью, поскольку неравновесны, но их стационарность существенно информационная. Из взаимосвязи полевых структур и процессов также следует информационная сущность взаимодействия физических полей.

Следовательно, информация реализуется в поэтапном развитии (движении), кратно ускоряя его (физическое сжатие времени).

Сменившая энергетическую, новая информационная «мировая цивилизация» может реализоваться и стать сколько-нибудь эволюционной в том случае, если информация получит полную физическую интерпретацию (как уголь и нефть - еще не энергия, так данные и сообщения - еще не информация).

\section{Глава 5.}

\section{Историко-футурологическая модель для информационного общества}

Модель построена на энциклопедических датах (начиная с н.э.):

\begin{tabular}{|c|c|c|c|}
\hline $\begin{array}{c}\text { Формачия } \\
\text { (производственно- } \\
\text { рыночная стадия) }\end{array}$ & $\begin{array}{c}\text { Начало } \\
\text { формации } \\
\text { (годыл с } \\
\text { отклонениями) }\end{array}$ & $\begin{array}{c}\text { Продолжи- } \\
\text { тельность } \\
\text { (лет) }\end{array}$ & Примечания \\
\hline $\begin{array}{l}\text { Первобытная } \\
\text { (последняя }\end{array}$ & 30720 до н.э. & 24576 & $\begin{array}{lcr}\text { Около } & 32720 & \text { лет } \\
\text { человек } & \text { начазад } & \text { трудиться }\end{array}$ \\
\hline
\end{tabular}


ISPC «Economy, technology, education and prospects for 2014», 30.01.2014

\begin{tabular}{|c|c|c|c|}
\hline $\begin{array}{l}\text { классического } \\
\text { первобытного } \\
\text { общества) }\end{array}$ & & & $\begin{array}{l}\text { рационально и защищать } \\
\text { результаты своего труда. } \\
\text { Зарождение рынка (точечно). }\end{array}$ \\
\hline $\begin{array}{l}\text { Рабовладельческая } \\
\text { (рабозахватническая) }\end{array}$ & $\begin{array}{l}6144 \text { до н.э. } \\
\text { (цивилизацион- } \\
\text { ная корреляция } \\
\text { минимальна) }\end{array}$ & 6144 & $\begin{array}{l}\text { Образование нового общества } \\
\text { (нового человека) - более } 8000 \\
\text { лет назад, что даже немногим } \\
\text { более, чем считается «от } \\
\text { сотворения мира» по многим } \\
\text { теологическим } \\
\text { (религиям, по Библии). В } \\
\text { Библии описано становление } \\
\text { рабовладельческого общества } \\
\text { из мелких древнееврейских } \\
\text { племен. }\end{array}$ \\
\hline Феодальная & $\begin{array}{l}1 \text { н.э. } \\
\text { Реальный } \\
\text { переход } \\
\text { 427г. }(419+8)\end{array}$ & $\begin{array}{r}1536 \\
{[1216]}\end{array}$ & $\begin{array}{l}\text { Дата начала «нового царствия } \\
\text { божьего на земле» известна как } \\
\text { рождение Христа (новая эра), } \\
\text { реальный переход - создание } \\
\text { вестготского королевства. } \\
\text { Римская Империя так и не } \\
\text { стала монархической и } \\
\text { развалилась. В конце стадии - } \\
\text { колонизация новых земель. }\end{array}$ \\
\hline Капиталистическая & $\begin{array}{l}1537 \\
1641 \text { (Англия) }\end{array}$ & $\begin{array}{r}384 \\
{[304]}\end{array}$ & $\begin{array}{l}\text { Начало - } \\
\text { протестантской } \\
\text { (Германия, Швейцария), далее } \\
\text { Голландия, реальный переход - } \\
\text { Англия. }\end{array}$ \\
\hline $\begin{array}{l}\text { Гос. } \\
\text { капиталистическая }\end{array}$ & $\begin{array}{l}1921 \\
1947 \text { (США) }\end{array}$ & $\begin{array}{r}96 \\
{[76]}\end{array}$ & 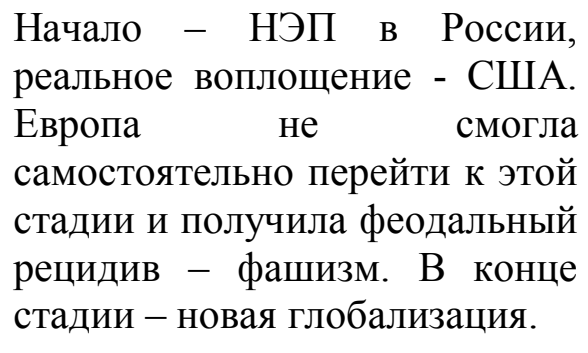 \\
\hline Временная стадия & Событие & 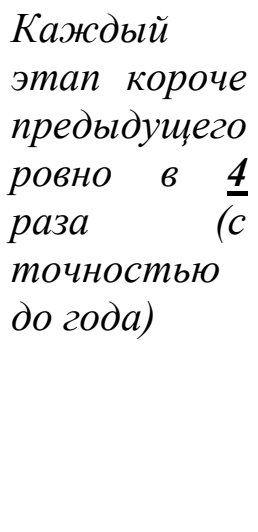 & 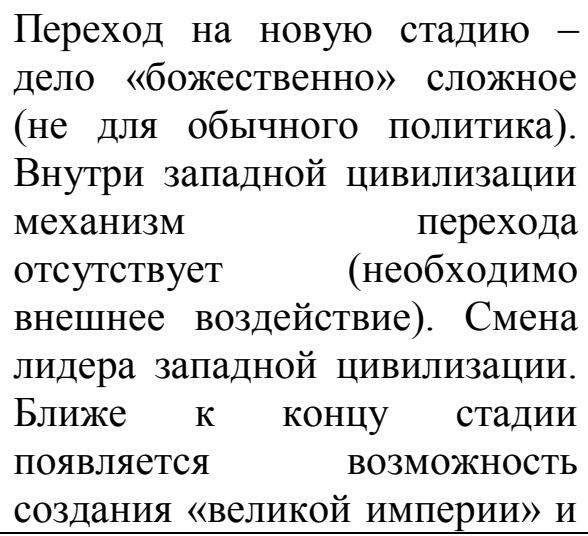 \\
\hline
\end{tabular}




\begin{tabular}{|l|l|l|l|}
\hline & & & начала «глобализации». \\
\hline $\begin{array}{l}\text { Социалистическая } \\
\text { (новая рыночная) }\end{array}$ & 2017 & 24 & $\begin{array}{l}\text { Планирование начальной } \\
\text { стадии постиндустриального } \\
\text { (прогноз) }\end{array}$ \\
& & $\begin{array}{l}\text { Проноцационного общества. } \\
\text { систем жизнеобеспечения }\end{array}$ \\
\hline
\end{tabular}

Всего к настоящему времени, как показано в таблице, современному человеку около 32720 лет, что вполне согласуется с данными археологов о времени появления кроманьонца (человеку, по результатам современной науки, несколько миллионов лет, а нашей планете на несколько порядков больше).

Первобытное общество отличается от первобытного стада рациональной деятельностью - производством в условиях зарождающегося рынка (нетоварного). Становление рабовладельческого общества описано в Библии (донаучно, но многое в настоящее время получает рациональное объяснение). Переход к феодальному обществу связан с христианством, а к капиталистическому - с протестантством либо подобным (в СССР трудовую этику поддерживала компартия, имевшая ячейки на каждом предприятии) мировоззрением.

Первая попытка перехода на новую стадию, как правило, не совсем удачна (например, Германия после Лютера или Россия после Ленина) из-за того, что эти страны отставали в развитии почти на стадию.

Преимущества нового способа производства и получения прибавочной стоимости проявляются ближе к середине стадии, в Англии, например, только после так называемой буржуазной революции (с 1642 г.), с которой началось новое время, хотя всегда утверждается, что капитализм зародился более чем на столетие раньше.

После каждой стадии - империализм (колонизация, глобализация). Если при колонизации экспансии подвергалась базовые ресурсы рабовладельческого рынка люди и земля (оккупация), то при глобализации экспансии подвергнутся базовые ресурсы капиталистического рынка - сырьевые (например, современная Россия пока не перестала быть глобальной колонией).

При постоянной кратности сохраняется ускорение развития цивилизаций (Россия, например, проходит стадии более чем в 5 раз быстрее, чем было у самой западной цивилизации). Это позволяет сокращать отставание и даже в некоторых аспектах выходить в лидеры.

От стадии к стадии меняется лидер западной цивилизации, так как внутри ее нет механизма перехода на следующую. Следовательно, требуется внешнее воздействие (переход осуществляется «на краю цивилизации»). Перестанут быть лидером и США. Кризисный способ развития западной цивилизации вновь вполне может привести ее на грань краха.

Задача - в определении синергетического механизма перехода для устойчивого развития. Эффект достигается при синтезе цивилизации и формации (стадии высшего из достижимых уровня, для современной России - госкапиталистической), согласовании материальной культуры с новой духовной (религиозной духовности недостаточно было даже для индустриализации 1925г.). Результат - новая цивилизация с новым мировоззрением и ускоренным развитием.

Постиндустриальное (как информационное) общество - пока не достигнуто (информационные технологии после упадка эйфории в начале нового тысячелетия стали всего лишь составляющими индустриального общества). Постиндустриальное общество на базе современной России - профанация, т.к. уровень технологического 
уклада отнюдь не повышается, а деградирует, причем довольно быстро (к доиндустриальному состоянию). России необходима высокотехнологическая модернизация (индустриализация) - 2009 год (состоялось провозглашение модернизации экономики). В 2011 году (за 10 лет до конца стадии - обратная волна) легко прогнозировалось начало упадка североамериканской цивилизации — новая депрессия.

История может и должна продолжиться и тогда впереди - новая стадия с новым способом познания - теперь живой природы. Постиндустриальный способ производства позволит создавать и использовать на ее принципах технические средства максимальной эффективности и экологической чистоты, вовлекая в производство (как для себя) и охватывая достойным уровнем жизни все большее количество людей.

На основе универсальной социально-экономической теории и исторической модели может базироваться действительно научно обоснованное планирование устойчивого достижения высшей стадии западной цивилизации без последующего краха.

А кратной волне соответствуют ограниченные поля (биополе...).

\section{Литература:}

1. Вебер М. Избранные произведения. М, 1990.

2. Гуревич А.Я. Теория формаций и реальность истории. ВФ, №11, 1990, стр. 31 43.

3. Кара-Мурза С.Г. Научная картина мира и фактор природы в экономике. Науковедение, №1, 1999.

4. Кондратьев Н.Д. Избранные сочинения. М, 1993.

5. Леонтьев В. Экономические эссе. М, 1990, стр. 217.

6. Маркс К. Капитал. М, 1955.

7. Моисеев Н.Н. Судьба цивилизации. Путь Разума. М, 1998.

8. Потемкин В.К., Симанов А.Л. Пространство в структуре мира. Новосибирск, 1990.

9. Розов Н.С. Структура социальной онтологии: по пути к синтезу макроисторических парадигм. ВФ, №2, 1999.

10. Соколов А.А., Тернов И.М. Квантовая механика и атомная физика. М., 1970 стр. $39 . . .40$.

11. Тойнби А.Д. Постижение истории. М, 1990.

12. Шрейдер Ю.А. Препятствие - логика. Природа, №1, 1992.

13. Энгельс Ф. и Маркс К. соч. т.28, стр. 209.

14. Яновен Ю. Кузык Б. Кушлин В. Прогноз инновационного развития России на период до 2050 года с учетом мировых тенденций. Главный инженер, № 9, 2005.

15. Система, симметрия, гармония», М, Мысль, 1988

16. Кузнецов Б.Л. Гипотеза синергетического рынка в свете феноменологической теории фазовых переходов Л.Ландау // Вопросы экономики, М., 2005, №8

Монография создана на основе статей, опубликованных в сборнике научных трудов Экономическая синергетика, ИнЭкА (КамПИ, филиал КФУ), г. Набережные Челны, 2005-10г.г. 